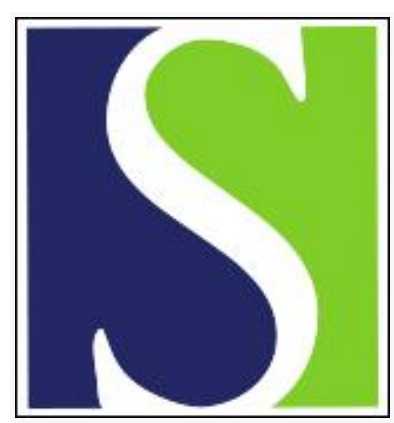

Scand J Work Environ Health 1983;9(1):25-29

https://doi.org/10.5271/sjweh.2446

Issue date: Feb 1983

A case-referent study on nasal cancer and exposure to wood dust in the province of Siena, Italy.

by Battista G, Cavallucci F, Comba P, Quercia A, Vindigni C, Sartorelli E

This article in PubMed: www.ncbi.nlm.nih.gov/pubmed/6857185

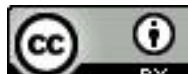




\title{
A case-referent study on nasal cancer and exposure to wood dust in the province of Siena, Italy
}

\author{
by Giuseppe Battista, MD, ${ }^{1}$ Francesco Cavallucci, MD, ${ }^{1}$ Pietro Comba, MSc, ${ }^{2}$ \\ Augusto Quercia MD, ${ }^{1}$ Carla Vindigni, MD, ${ }^{3}$ Emilio Sartorelli, MD ${ }^{1}$
}

\begin{abstract}
BATTISTA G, CAVALLUCCI F, COMBA P, QUERCIA A, VINDIGNI C, SARTORELLI B case-referent study on nasal cancer and exposure to wood dust in the province of E. A case-referent study on naviron health 9 (1983) $25-29$. The aim of the present study Siena, Italy. Scand $j$ work environ health 9 (1983) furniture industry in the province of Siena, Italy. Four to seven percent of the active male population is employed in this sector. A case-referent approach was used. The male population is employed in this the Ear, Nose and Throat Clinic and the Radiotherapy Unit of Siena and diagnosed as having cancer of the nasal cavities or paranasal sinuses between 1963 and 1981 . The referents were male patients admitted to the Medical Clinic of Siena for all causes except nasal neoplasia; they were matched $5: 1$ to the cancer patients for age and time of admission. Information was gathered (by postal questionpatients for age and time of admission. Information was gathered and 164 of the 180 naires) on the occupational ho odds ratio associated with exposure to wood dust was $5.4(1.7-17.2)$ for all carcinomas, and $89.7(19.8-407.3)$ for mucinous adenocarcinoma. The woods used by the exposed cancer patients were mainly oak, chestnut, poplar, and fir. The median duration of exposure was 40 years; no exposed cancer patient reported the presence of exhaust systems in their work environment.
\end{abstract}

Key terms: furniture industry, mucinous adenocarcinoma, occupational cancer, wood industry.

A causal association between employment in the furniture industry and adenocarcinoma of the nose and sinuses was reported by Acheson et al in Great Britain (1) and subsequently confirmed by other authors; an evaluation of the literature of the last 15 years can be found in a recent monograph by the International Agency for Research on Cancer (7). The excess risk was mainly found among people exposed to wood dust. Nasal cancer of other histological types may also occur at a higher rate among these workers. Lumber and sawmill industries (including logging) and car-

1 Institute of Occupational Medicine, University of Siena, Siena, Italy.

2 Istituto Superiore di Sanità, Rome, Italy.

3 Second Unit of Pathological Anatomy, University of Siena, Siena, Italy.

Reprint requests to: $\mathrm{Dr} G$ Battista, Istituto di Medicina del Lavoro, Via dei Tufi 1, Siena, Italy. pentry and joinery may be associated with increased risk, but the evidence is so far inadequate.

Because of the low incidence of nasal cancers, the case-referent approach proved to be suitable to test the association of this disease with occupational exposures in the wood and furniture industry $(4,5$, $8,11,13)$, given that the proportion of exposed people in the population under study were not too low.

The aim of the present study was to provide estimates of the association between nasal cancer and occupational exposure to wood dust in the province of Siena. The proportion of the active population employed in the wood and furniture industry is quite relevant in this area, as can be seen from table 1 . The access of the population to medical facilities is rather well known, and the hospital files are reliable. A case-referent study was 
regarded as informative in light of the ongoing discussion on validity issues in case-referent studies $(2,6,9)$.

A preliminary presentation of this study was given at the 44th Conference of the Italian Society of Occupational Medicine and Industrial Hygiene (3).

\section{Material and methods}

All cases of malignant tumors of the nose and paranasal sinuses referred to the Ear, Nose and Throat Clinic and the Radiother-

Table 1. Proportion of the active population employed in the wood and furniture industry. Data from the 1961 and 1971 rational censuses (expressed as percentages).

\begin{tabular}{lccccc}
\hline & \multicolumn{2}{c}{1961} & & \multicolumn{2}{c}{1971} \\
\cline { 2 - 3 } \cline { 5 - 6 } & Men & Women & & Men & Women \\
\cline { 2 - 3 } $\begin{array}{l}\text { Italy } \\
\begin{array}{l}\text { Province } \\
\text { of Siena }\end{array}\end{array}$ & 3.29 & 0.76 & & 3.01 & 1.14 \\
\hline
\end{tabular}

apy Unit of Siena from 1963 to 1981 were considered. These cases can be said to include all those that occurred in the province of Siena during the study period, plus a certain number of cases in which the patient's residence was outside the province. Clinical records and pathological specimens were retrieved. Three pathologists reviewed the slides of each case and classified them according to the guidelines of the World Health Organization (12). The study was restricted to patients affected by carcinomas of the nasal cavities and paranasal sinuses, cases of neoplasia of the dorse and vestibule and histological types other than epithelial malignancies being excluded.

The cases included 36 men and 17 women. It was estimated that, given the low number of females and the relatively lower proportion of females employed in the wood and furniture industry, the case-referent approach should be restricted to the men. Five referents were matched to each cancer patient; the referents were randomly selected from men of the same age ( \pm 1 year) admitted to the Medical Clin.

Table 2. Cases by sex of patients, site and histological type.

\begin{tabular}{|c|c|c|c|c|c|c|c|c|c|c|c|c|c|c|}
\hline & \multicolumn{2}{|c|}{ Nasal cavities } & \multicolumn{2}{|c|}{ Nasal septum } & \multicolumn{2}{|c|}{ Ethmoid } & \multicolumn{2}{|c|}{ Maxillary sinus } & \multicolumn{2}{|c|}{ Frontal sinus } & \multicolumn{2}{|c|}{ Unidentified } & \multicolumn{2}{|r|}{ Total } \\
\hline & Men & Women & Men & Women & Men & Women & Men & Women & Men & Women & Men & Women & Men & Women \\
\hline \multicolumn{15}{|l|}{ Squamocellular } \\
\hline $\begin{array}{l}\text { carcinoma } \\
\text { Respiratory }\end{array}$ & 3 & 1 & 3 & - & 4 & - & 7 & 2 & - & - & - & - & 17 & 3 \\
\hline cells carcinoma & 2 & 2 & - & - & 1 & 1 & 5 & 4 & - & - & - & 1 & 8 & 8 \\
\hline $\begin{array}{l}\text { Adenocarcinoma } \\
\text { Mucinous adeno- }\end{array}$ & - & - & - & - & - & - & - & - & - & - & - & 1 & - & 1 \\
\hline $\begin{array}{l}\text { carcinoma } \\
\text { Adenoid cystic } \\
\text { carcinoma }\end{array}$ & 1 & - & - & - & 2 & - & 2 & 1 & - & - & - & 1 & 5 & 2 \\
\hline (cylindroma) & - & - & - & - & - & - & 2 & 3 & 2 & - & - & - & 4 & 3 \\
\hline Anaplastic carcinoma & 1 & - & - & - & - & - & 1 & - & - & - & - & - & 2 & - \\
\hline All carcinomas & 7 & 3 & 3 & - & 7 & 1 & 17 & 10 & 2 & - & - & 3 & 36 & 17 \\
\hline
\end{tabular}

Table 3. Male cases by histological type and occupational category

\begin{tabular}{lcccccr}
\hline & $\begin{array}{c}\text { Wood and } \\
\text { furniture }\end{array}$ & $\begin{array}{c}\text { Agri- } \\
\text { culture }\end{array}$ & $\begin{array}{c}\text { Industry } \\
\text { (except } \\
\text { wood and } \\
\text { furniture) }\end{array}$ & $\begin{array}{c}\text { Handi- } \\
\text { craft }\end{array}$ & Other & Total \\
\cline { 2 - 7 } & 1 & 7 & 4 & 1 & 4 & $17(47.2 \%)$ \\
$\begin{array}{l}\text { Squamocellular carcinoma } \\
\text { Respiratory cells carcinoma }\end{array}$ & 1 & 1 & 2 & 2 & 2 & $8(22.2 \%)$ \\
$\begin{array}{l}\text { Mucinous adenocarcinoma } \\
\text { Adenoid cystic carcinoma }\end{array}$ & 4 & 1 & - & - & - & $5(13.9 \%)$ \\
$\begin{array}{l}\text { (cylindroma) } \\
\text { Anaplastic carcinoma }\end{array}$ & 1 & - & 1 & - & -2 & $4(11.1 \%)$ \\
\hline All carcinomas & 7 & 10 & 8 & 3 & $8.6 \%)$ \\
\hline
\end{tabular}


ic of Siena at the same time ( \pm 3 months) as the cancer patients under study. All diagnoses other than nasal neoplasia were accepted. The cancer patients and referents received a letter explaining that the Institute of Occupational Medicine was conducting a study on the occupations of people admitted to the hospitals of Siena between 1963 and 1981, and they were asked to fill out a questionnaire containing general questions on current occupation, past occupations, duration of employment in each occupation, and three specific questions about having ever worked in the wood industry, in the furniture industry, and in the shoe and leather industry. Phone calls were made to those who did not answer by mail; for the 29 cancer patients and 81 referents who had died, the next of kin were interviewed. Information was gathered on all of the 36 cancer patients and on 164 of the 180 referents. Those subjects who had been employed as woodworkers or cabinet makers were defined as exposed to wood dust; one cancer patient who had worked five years as a truck driver in a furniture factory was not considered exposed.
Estimates of the rate ratio were computed both with allowance for matching, according to the technique of Miettinen, as described by Rothman \& Boice (10), and after dissolution of matched sets (odds ratio). The $95 \%$ confidence intervals were computed according to the procedure of Miettinen (9).

\section{Results}

Table 2 shows the site and histological pattern of the observed cancers for both sexes. Table 3 shows the male cancer patients by occupation; it can be seen that four out of the five cases of mucinous adenocarcinoma came from the wood and furniture industry. Table 4 shows the results of the case-referent approach; the rate ratio and its $95 \%$ confidence interval were estimated as $4.7(1.7-12.8)$, with allowance for matching, and $5.4(1.7-17.2)$ after dissolution of the matched sets. The two point and interval estimates were in good agreement. When we considered adenocarcinomas only, the rate ratio became much higher, 89.7 (19.8-407.3).

We then considered the data relative to the subjects residing in the province

Table 4. Results of the case-referent study.

\begin{tabular}{lcccc}
\hline & \multicolumn{4}{c}{ Number of exposed referents } \\
\cline { 2 - 5 } Cancer patients & 0 & 1 & $2-5$ & (sets with 3 referents) \\
\hline Exposed & 1 & - & - & \\
Not exposed & 2 & 1 & - & (sets with 4 referents) \\
Exposed & 2 & - & - & (sets with 5 referents) \\
Not exposed & 4 & 2 & - & \\
Exposed & 3 & 1 & - & - \\
Not exposed & 17 & 3 & &
\end{tabular}

Table 5. Incidence of nasal cancer and adenocarcinoma in the active male population of the province of Siena (1963-1981).

\begin{tabular}{|c|c|c|c|}
\hline & $\begin{array}{c}\text { All } \\
\text { carcinomas }\end{array}$ & $\begin{array}{l}\text { Mucinous } \\
\text { adeno- } \\
\text { carcinoma }\end{array}$ & $\begin{array}{l}\text { Person- } \\
\text { years }\end{array}$ \\
\hline $\begin{array}{l}\text { Wood and furniture industry } \\
\text { Other occupations }\end{array}$ & $\begin{array}{r}4 \\
16\end{array}$ & $\begin{array}{l}3 \\
1\end{array}$ & $\begin{array}{r}108,395 \\
1,298,593\end{array}$ \\
\hline Rate ratio & $3.0(0.8-11.1)$ & \multicolumn{2}{|c|}{$35.9(6.5-198.4)$} \\
\hline
\end{tabular}


Table 6. Occupational exposures to wood and smoking habits of the cancer patients.

\begin{tabular}{|c|c|c|c|c|c|c|c|}
\hline & \multicolumn{7}{|c|}{ Case number } \\
\hline & 1 & 2 & 3 & 4 & 5 & 6 & 7 \\
\hline $\begin{array}{l}\text { Age at diagnosis (years) } \\
\text { Length of exposure (years) } \\
\text { Woods }\end{array}$ & $\begin{array}{l}70 \\
49 \\
\text { Chestnut, } \\
\text { walnut, alder }\end{array}$ & $\begin{array}{l}54 \\
34 \\
\text { Oak, } \\
\text { chestnut }\end{array}$ & $\begin{array}{r}40 \\
6 \\
\text { Oak }\end{array}$ & $\begin{array}{c}63 \\
10 \\
\text { Poplar, } \\
\text { fir, beech }\end{array}$ & $\begin{array}{l}62 \\
45 \\
\text { Chestnut, } \\
\text { poplar, oak, } \\
\text { acacia }\end{array}$ & $\begin{array}{l}\quad 53 \\
\quad 40 \\
\text { Fir, oak, } \\
\text { turkey oak }\end{array}$ & $\begin{array}{l}79 \\
\quad 65 \\
\text { Poplar, } \\
\text { chestnut }\end{array}$ \\
\hline $\begin{array}{l}\text { Histological type } \\
\text { Cigarette consumption } \\
\text { (number/d) }\end{array}$ & $\begin{array}{l}\text { Mucinous } \\
\text { adenocar- } \\
\text { cinoma } \\
\text { Former } \\
\text { smoker }\end{array}$ & $\begin{array}{l}\text { Mucinous } \\
\text { adenocar- } \\
\text { cinoma } \\
\text { Non- } \\
\text { smoker }\end{array}$ & $\begin{array}{l}\text { Adenoid cys- } \\
\text { tic carcinoma } \\
\text { (cylindroma) } \\
20\end{array}$ & $\begin{array}{l}\text { Squamo- } \\
\text { cellular } \\
\text { carcinoma } \\
\quad 20\end{array}$ & $\begin{array}{l}\text { Mucinous } \\
\text { adenocar- } \\
\text { cinoma } \\
1-2\end{array}$ & $\begin{array}{l}\text { Respiratory } \\
\text { cells car- } \\
\text { cinoma } \\
\text { Non- } \\
\text { smoker }\end{array}$ & $\begin{array}{l}\text { Mucinous } \\
\text { adenocar- } \\
\text { cinoma } \\
\quad 20\end{array}$ \\
\hline
\end{tabular}

of Siena (table 5). It was possible to estimate the incidence of nasal cancers and mucinous adenocarcinomas among the male population active in the wood and furniture industry and in other occupations. Person-years at risk were estimated from the data of the 1971 national census. The rate ratios (and $95 \%$ confidence intervals) were $3.0(0.8-11.1)$ and 35.9 (6.5-198.4) for all carcinomas and mucinous adenocarcinomas, respectively.

Table 6 provides some information on the woods that were used in the shops of the exposed cancer patients and the time these men spent in this occupation. Except in cases 3 and 4, involving men exposed to wood dust in the $1960 \mathrm{~s}$, all the cancer patients had started employment in the wood and furniture industry before the Second World War. There were no data available from hygienic surveys, but it resulted that few people used to be employed in these shops, and there were no exhaust systems.

\section{Discussion}

Our results seem to be in good agreement with those of other authors that have studied the association between occupational exposure to wood dust and nasal cancer (7). We used the World Health Organization's classification of histological types, even though it has been criticized for its too sharp distinction between adenocarcinoma and mucinous adenocarcinoma (RH Cowdell, personal communication; $\mathrm{P}$ Ironside, personal communication). Mucinous adenocarcinoma is the main response to the carcinogenic agent present in wood dust.

No major information bias is likely to have affected the study. Nasal cancer in a woodworker does not yet receive compensation in Italy as an occupational disease, and the issue of carcinogenic risks in the wood industry has not been discussed so far other than in specialized meetings. Therefore there should be no differential recalls of exposure among the cancer patients and referents studied. Furthermore the use of a simple questionnaire with few, clear questions made the classification of subjects into exposure categories rather straightforward.

The etiologic fraction for the exposed, with respect to all carcinomas, was 0.81 in the case-referent approach and 0.67 from incidence data; the corresponding fractions for the general population are 0.16 and 0.13 , respectively. If we consider mucinous adenocarcinoma, the etiologic fractions for the exposed are 0.99 (case-referent) and 0.97 (incidence data), and the etiologic fractions for the general population are 0.79 and 0.71 , respectively. We can thus reasonably think that all mucinous adenocarcinomas among the exposed were causally related to the exposure.

\section{Acknowledgment}

The authors wish to thank Prof O Axelson of the University of Linköping for his helpful criticism and suggestions.

\section{References}

1. Acheson ED, Hadfield EH, Macbeth RG. Carcinoma of the nasal cavity and accessory sinuses in woodworkers. Lancet 1 (1967) 311-312.

2. Axelson $O$. The case-referent (case-control) study in occupational health epidemiology. Scand $j$ work environ health 5 (1979) 91-99.

3. Battista G, Quercia A, Sartorelli E, Cintorino M, Comba P. Cancro delle fosse nasali 
e dei seni paranasali e esposizione a polveri. di legno: Studio caso-controllo. In: Atti $44^{\circ}$ Congresso Nazionale Società Italiana di Medicina del Lavoro e Igiene Industriale, Padova 1981.

4. Brinton LA, Blot WJ, Stone BJ, Fraumeni JF. A death certificate analysis of nasal cancer among furniture workers in Northern Carolina. Cancer res 37 (1977) 34733474.

5. Cecchi F, Buiatti E, Kriebel D, Nastasi L, Santucci M. Adenocarcinoma of the nose and paranasal sinuses in shoemakers and woodworkers in the province of Florence, Italy (1963-1977). Br $\mathrm{j}$ ind med 37 (1980) $222-225$.

6. Ibrahim MA, Spitzer WO, ed. The casecontrol study: Consensus and controversy. $\mathrm{J}$ chronic dis 32 (1979) $1-144$.

7. International Agency for Research on Cancer. Wood, leather and some associated industries. Lyon 1981. (IARC monographs on the evaluation of the carcinogenic risk of chemicals to man, volume 25).

8. Merler E, Carnevale F, D'Andrea F, Solari PL. A case-control study in the aetiology of nose carcinoma in Verona. In: Proceed- ings of the international symposium on prevention of occupational cancer, Helsinki 1981.

9. Miettinen OS. Estimability and estimation in case-referent studies. Am j epidemiol 103 (1976) 226-235.

10. Rothman KJ, Boice DJ. Epidemiologic analysis with a programmable calculator. National Institutes of Health, Washington, DC 1979. (Publication no 79-1649).

11. Roush GC, Meigs JW, Kelly J, Flannery JT, Burdo H. Sinonasal cancer and occupation: A case-control study. Am j epidemiol 111 (1980) 183-193.

12. Shanmugaratnam K, Sobin LH. Types histologiques des tumeurs des voies aériennes supérieures. Organisation Mondiale de la Santé, Genève 1978.

13. Tola S, Hernberg S, Collan Y, Linderborg $\mathrm{H}$, Korkala ML. A case-control study of the etiology of nasal cancer in Finland. Int arch occup environ health 46 (1980) 79-85.

Received for publication: 19 July 1982 